\title{
Eloqüência, liberdade e educação no Dialogus de oratoribus
}

\author{
Ariovaldo A. Peterlini \\ Universidade de São Paulo \\ Brasil
}

Resumo. Visa o trabalho trazer à consideração de hoje idéias e fatos selecionados no Dialogus de oratoribus, de Tácito, como auxílio ao melhor entendimento do significado da maior ou menor liberdade de ser e expressar-se, consoante o sistema político e o educacional, bem como da atuação da eloqüência nessa liberdade. A oratória tida por decadente na época de Tácito, embora vista ainda como arte de proteção e salvação é raramente, quase a medo, tratada à luz da política dominante. A educação falha e a "paz" política seriam as causas dessa decadência na época imperial. Na visão romana, a liberdade propriamente dita, a absoluta libertas, depende inicialmente dos educadores. A liberdade está também condicionada ao grau de conhecimento, em cuja área a persuasão "democrática" da eloqüência pode licitamente agir, e a uma política capaz de respeitar essa liberdade. No Império, a eloqüência não se suicidaria, ousando contra o príncipe. Daí que, no dizer de Syme, a oratória que sobrevivia então era o "modelo da eloqüência forense dos acusadores, aquela eloqüência que jorrava sangue e tresandava a ganhos ilícitos". As escolas tinham nisso parte grande, em virtude da superficialidade da educação na época. Tendo vivido e vivendo sob a pressão dos imperadores, embora deixe entrever sua angústia, Tácito acomoda-se para sobreviver, mas descobre uma maneira de ensinar a verdade, narrando o que aconteceu no passado, porque a maior parte das pessoas aprende com o que acontece aos outros (plures aliorum euentis docentur).

Palavras-chave. Dialogus de oratoribus; Tácito; retórica; eloqüência; liberdade; educação romana; política romana.

Assaz conhecida é a fantasia do homem de poder voltar ao ontem, para conseguir modificar comportamentos que redundaram em indesejáveis conseqüências do hoje. A ficção, máxime no cinema, tem usado e abusado dessas viagens ao tempo passado, sem dar-se conta de que, em idênticas circunstâncias, o homem vem, na essência de seus atos, repetindo o homem e de que é possível deparar na história da humanindade, em cada geração, o reiterar de fatos bons, maus ou indiferentes, consoante nossos critérios,

${ }^{1}$ Faculdade de Filosofia, Letras e Ciências Humanas, Departamento de Letras Clássicas e Vernáculas. 
a ponto de não ser difícil a um historiador provido de senso e olhos de ver, ponderadas as semelhanças de situações e causas, a previsão, com alta probabilidade, do que vai suceder amanhã.

Atento o fato de que o homem pode fazer tudo o que um homem pode fazer, mas só o que um homem pode fazer, embora variem instrumentos e meios, a humanidade no fundo se repete, mesmo na ousadia do ruit per uetitum nefas de Horácio, lançando-se pelo sacrilégio proibido no vôo de Ícaro, no vôo da asa delta; no romper os mares com que os deuses separaram as terra, no buscar os astros em naves espaciais; na ousadia de uma ü $\beta$ pıs que faz do homem sempre um "extra vagante" para além dos limites aceitos, avançando de contínuo nos mistérios da natureza, para além do átomo, do DNA, da geração normal, do transgênico, do desconhecido, a qualquer preço....

Como poderia Cícero afirmar, na cola de alguns historiadores gregos, historia ... testis temporum, lux ueritatis, uita memoriae, magistra uitae, nuntia uetustatis ${ }^{2}$ se não fosse possível aplicar no presente as lições do passado ou se de nada aproveitassem hoje as mensagens de tempos idos? Tácito vai mais longe ainda, quando alude nos Anais à idéia do eterno retorno: nisi forte rebus cunctis inest quidam uelut orbis, ut quem ad modum temporum uices, ita morum uertantur ${ }^{3}$.

Assim é que este trabalho leva em mira a tentativa de transpor a outras mãos, de normal mais jovens, algumas idéias e fatos selecionados na pequena obra de Tácito Dialogus de oratoribus, para trazê-los à consideração de nossos dias como auxílio a um melhor entendimento do significado da maior ou menor liberdade de ser e expressar-se, consoante o sistema político e o educacional, bem como a atuação da eloqüência nessa liberdade.

Cornélio Tácito, só para lembrar, viveu da metade do século I até os anos 20 do século II, portanto sob o domínio de 10 imperadores, sendo que, acredito, só pôde dar-se conta da realidade política romana depois dos 20 anos de idade, ou seja, sob Vespasiano, um governo que, em relação aos das loucuras de Calígula, Nero, Galba, Otão e Vitélio, mostrou sensatez na administração do Império, na economia, na justiça e na ordem, não obstante algumas atrocidades e perseguições políticas. Tito, filho de Vespasiano, foi o caso raro de alguém que se tornou melhor depois de assumir o poder. Domiciano esqueceu logo o governo promissor de seus inícios e derivou para a tirania de condenações e confiscos arbitrários. Sob os Antoninos, Tácito teve por governo a Nerva, de quem disse que "harmonizou duas coisas an-

2 "A história ... testemunha dos tempos, luz da verdade, vida da memória, mestra da vida, mensageira do passado" (Cic. De orat. II, 9, 36).

3 "A menos que, talvez, haja em todas as coisas um como ciclo, de sorte que, à maneira dos ciclos das estações, assim se alternem os dos costumes" (Tac. An. III, 55, 5). 
teriormente incompatíveis, o principado e a liberdade."'. A Nerva seguiu-se o austero, mas nem sempre justo Trajano e, por fim, Adriano, político experiente, a despeito das mazelas quase normais nos imperadores romanos.

Advogado de renome e orador de profissão, Tácito, quando jovem, acompanhava, a par com seus estudos, como faziam os estudantes de retórica do período republicano, os oradores de nomeada de sua época, Marco Apro e Júlio Segundo, nos trabalhos do fórum.

Sob Vespasiano entrou a receber honrarias: foi pretor sob Domiciano e, por alguma missão em província, esteve ausente de Roma até 93. Voltou a tempo de assistir aos horrores dos últimos anos do governo de Domiciano. Sob Tito, foi cônsul e ainda procônsul na Ásia.

O Dialogus de oratoribus, uma das obras menores de Tácito, foi provavelmente a primeira a ser escrita, sob Tito, aí por 81 d.C., ou entre 102 e 105 consoante acredita Alain Michel ${ }^{5}$, baseado no fato de que Fábio Justo, a quem Tácito dirige o Dialogus, como resposta, só foi cônsul em 102, embora o nome cônsul não venha na obra. Muito se discutiu o estilo ciceroniano do Dialogus, diverso do das obras posteriores, o que se tem tentado explicar principalmente pela exigência dos gêneros, aqui do sermo e lá da historia, além do influxo dos diálogos De oratore, De republica, De natura deorum e Brutus, de Cícero, um exemplo proposto por Quintiliano, o mestre maior da época de Tácito. Argumentam alguns que, nas próprias obras históricas de Tácito, quando se relata um discurso, o estilo se diversifica.

Postos esses dados externos à obra. mas não alheios a ela, e deixando de parte os múltiplos problemas e discussões que a têm acompanhado, vamos ater-nos apenas ao exame de alguns aspectos do Dialogus atinentes às relações entre educação, liberdade e eloqüência.

Consoante as considerações iniciais do Dialogus, praticamente uma introdução do próprio Tácito, a obra toda é uma resposta do autor, mediante os artifício de um diálogo, a uma consulta de Fábio Justo. Vejamos o texto:

Saepe ex me requiris, Iuste Fabi, cur, cum priora saecula tot eminentium oratorum ingeniis gloriaque floruerint, nostra potissimum aetas deserta et gloriae eloquentiae orbata uix nomen ipsum oratoris retineat;neque enim ita appellamus nisi antiquos, horum autem temporum diserti causidici et aduocati et patroni et quiduis potius quam oratores uocantur. ${ }^{6}$

${ }^{4}$ Sed quamquam primo statim saeculi ortu Nerua Caesar res olim dissociabilis miscuerit, principatum ac libertatem (Tac. Agricola, III, 1).

${ }^{5}$ Michel, A. Histoire des doctrines politiques a Roma. Paris, Presses Universitaires de France, 1971.

6 "Muitas vezes me perguntas, Justo Fábio, por que, ao passo que os séculos precedentes floresceram com a fama dos talentos de tantos oradores insignes, a nossa época, realmente 
Não obstante a longa defesa que da eloqüência de sua época faz o interlocutor Marco Apro no Dialogus, fica evidente, na introdução acima, que de normal a visão que os capazes de espírito crítico então tinham da eloqüência contemporânea era de decadência em relação ao período áureo anterior ao Império.

O próprio Apro nos deixa entrever a que se reduzira, numa perspectiva bem estreita, o objetivo da eloqüência em seu tempo:

Nam si ad utilitatem uitae omnia consilia factaque nostra derigenda sunt, quid est tutius quam eam exercere artem, qua semper armatus praesidium amicis, opem alienis, salutem periclitantibus, inuidis uero et inimicis metum et terrorem ultro feras, ipse securus et uelut quadam perpetua potentia ac potestate munitus??

Curiosamente, o ângulo político da eloqüência no Dialogus apenas aponta de raro, aqui e ali, quase a medo, como v.g. na passagem em que Materno incentiva Messala a declinar as causas da decadência da oratória: "Perge" inquit Maternus "et cum de antiquis loquaris, utere antiqua libertate, a qua uel magis degenerauimus quam ab eloquentia".

A educação mal orientada e a "paz" política (não se diz a que preço conseguida) são os motivos principais elencados por Messala como causas da decadência da oratória nessa época imperial. Pela comparação entre como se formavam os jovens oradores no período republicano e como se educavam no tempo de Tácito, pode ver-se quanto a superficialidade e a pobreza de conhecimentos substituíram a seriedade e a amplitude do saber dos antigos:

Nam pridem suus cuique filius, ex casta parente natus, non in cellula emptae nutricis, sed gremio ac sinu matris educabatur, cuius praecipua laus erat tueri domum et inseruire liberis. Eligebatur autem maior aliqua natu propinqua, cuius probatis spectatisque moribus omnis eiusdem familiae suboles committeretur; coram qua neque dicere faz erat quod turpe dictu, neque facere quod inhonestum factu uideretur. Ac non stu-

abandonada e desprovida da glória da eloqüência, mal conserva o próprio nome de orador; na verdade, não chamamos assim senão os antigos; os eloqüentes, porém, de nosso tempo são nomeados como causídicos, advogados, defensores, de preferência a oradores" (Tac. Dial. I,1).

7 "Com efeito, se todos os nossos desígnios e ações devem ser orientados para a utilidade da vida, que há de mais seguro do que praticar aquela arte, armado da qual possa alguém levar proteção aos amigos, ajuda aos demais, salvação aos que correm perigo e, por outro lado, além disso, medo e mesmo terror aos invejosos e aos adversários, ficando o próprio orador seguro e defendido como que por uma força e um poder legal perpétuos?" (Tac. Dial. V,4).

8 "Vamos, disse Materno, e já que falas dos antigos, usa da antiga liberdade, da qual degeneramos talvez mais do que da eloqüência" (Tac. Dial. XXVII, 3). 
dia modo curasque, sed remissiones etiam lususque puerorum sanctitate quadam ac uerecundia temperabat. ${ }^{9}$

A essa educação inicial antiga, preocupada e cuidadosa Tácito, pela voz de Messala, contrapõe a de sua época, ecoando uma queixa também de outros escritores romanos, como v.g. de Quintiliano ${ }^{10}$ :

At nunc natus infans delegatur Graeculae alicui ancillae, cui adiungitur unus aut alter ex omnibus seruis, plerumque uilissimus nec cuiquam serio ministerio adcommodatus. Horum fabulis et erroribus uirides statim et rudes animi imbuuntur; nec quisquam in tota domo pensi habet, quid coram infante domino aut dicat aut faciat. Quin etiam ipsi parentes non probitati neque modestiae paruulos adsuefaciunt, sed lasciuiae et dicacitati, per quae paulatim impudentia inrepit et sui alienique contemptus. Iamque uero propria et peculiaria huius urbis uitia paene in utero matris concipi mihi uidentur, histrionalis fauor et gladiatorum equorumque studia: quibus occupatus et obsessus animus quantulum loci bonis artibus relinquit? Quotum quemque inuenies qui domi quicquam aliud loquatur? Quos alios adulescentorum sermones excipimus, si quando auditoria intrauimus? Ne praeceptores quidem ullas crebriores cum auditoribus suis fabulas habent; colligunt enim discipulos non seueritate disciplinae nec ingenii experimento, sed ambitione salutationum et inlecebris adulationis. ${ }^{11}$

9 "Outrora, com efeito, o filho de cada um, nascido de mãe casta, era criado não no quartinho de uma ama comprada, mas no seio e no regaço de sua mãe, cuja precípua glória era administrar a casa e dedicar-se a seus filhos. Escolhia-se também uma parente um tanto idosa, a cujas virtudes excelentes e reconhecidas se pudesse confiar toda a prole de uma mesma casa; não era permitido dizer em sua presença o que parecesse vergonhoso de ser dito nem fazer o que parecesse desonesto de ser feito. Era a mãe que regulava, com certa seriedade e pudor, não só os estudos e deveres, mas também as distrações e os jogos dos meninos" (Tac. Dial. XXVIII, 4-6).

${ }^{10}$ Inst. Or. I, 1,4; I, 2, 7-8.

11 "Agora, porém, a criança, tão logo nasce, é entregue a qualquer criadinha grega, à qual se juntam um ou dois dos escravos, quaisquer deles, na maioria das vezes em extremo medíocres e despreparados para serviços sérios. De suas histórias e superstições se impregnam para logo os verdes e tenros ânimos; não há ninguém em toda a casa que se preocupe com o que diz ou faz diante do menino, seu senhor. E vai além: os próprios pais habituam os pequeninos não para a decência e a modéstia, mas sim para o mau comportamento e a zombaria e por aí, aos poucos, se introduzem a impudência e o desprezo de si e dos outros. Parece-me que até o vícios próprios e peculiares desta Cidade, ou seja, o gosto por atores e o entusiasmo por gladiadores e cavalos, são concebidos no útero materno. Ocupado e obcecado por eles, que espaço tão diminuto não deixa o espírito para os estudos sérios?! Em que número e quem se encontrará que fale em casa de outra coisa? Que outras conversas de adolescentes ouvimos nós, se alguma vez entramos nas salas de aulas? Nem mesmo os próprios professores têm com os seus ouvintes assuntos de conversa mais graves; atraem realmente os discípulos, 
Antes de examinarmos a visão que Messala, principalmente, apresenta da educação dirigida à eloqüência, em sua época, vejamos alguma coisa sobre como os romanos viam a liberdade. Eles sabiam, já pela experiência, já porque a Grécia lhes ensinara, que a liberdade propriamente dita chega tardiamente, após anos de educação; que não é apenas uma iniciação aos princípios, mas uma formação à liberdade, no árduo trabalho, diz Aristóteles, de levar a potência ao ato. Como não alcançamos, por nós mesmos, começar essa difícil operação, são os educadores que vão empreendê-la no início. A maneira pela qual somos educados tem uma importância capital ${ }^{12}$.

Sem liberdade, a educação verdadeira, que é um processo interior, imanente, análogo ao da assimilação dos alimentos, não pode existir; só um sujeito livre, consciente e inteligente é passível de educação, sendo que a própria educação, na medida em que cresce, cresce a liberdade. Só podemos pensar com as idéias que temos e, sem dúvida, a nossa liberdade tem o tamanho de nossos conhecimentos, onde se encontra o maior ou menor número de nossas opções. Vem daí a importância extrema dos nossos primeiros educadores, que, se tiverem mais ampla visão filosófica do homem e gozarem de liberdade para educar, consoante essa visão vão poder orientar seus educandos para que se realizem como homens na integridade de suas verdadeiras possibilidades ${ }^{13}$.

Sêneca nos dá, em alguns passos das Cartas a Lucílio, sua concepção de liberdade. Expõe ele a sua visão da "absoluta libertas", abrangendo a liberdade exterior, social, política e econômica e a liberdade interior, em face da ignorância de si mesmo e da pressão das paixões:

Quaeris quae sit ista? Non homines timere, non deos; nec turpia uelle nec nimia; in se ipsum habere maximam potestatem: inaestimabile bonum est suum fieri. ${ }^{14}$

Quae sit libertas, quaeris? Nulli rei seruire, nulli necessitati, nullis casibus, fortunam in aequum deducere. ${ }^{15}$

não pela severidade da disciplina, não pela comprovação do seu talento, mas pela adulação dos cumprimentos e pelas seduções da lisonja" (Tac. Dial. XXIX,1-4).

${ }_{12}$ Aristóteles, Ética a Nicômaco, II, I, 3 (apud GoBry, I. La philosophie pratique d'Aristote. Lyon, Presses Universitaires de Lyon, 1995, p. 57-65).

${ }_{13}$ Sciacca, M.F. El problema de la educación. Trad. Juan J. Ruiz Cuevas. Barcelona, Luis Miracle Ed., 1957, p. 38-40.

14 “Indagas que liberdade é essa? Não temer os homens nem os deuses; não querer nem o desonesto nem o excessivo; ter sobre si um poder total: é um bem inestimável tornar-se dono de si mesmo" (Sen. Ad Luc. 75, 18).

15 "O que é a liberdade, perguntas? Não ser escravo de coisa alguma, de nenhuma necessidade, de nenhum acaso; encarar a fortuna frente a frente" (Sen. Ad Luc. 51,9). 
E é pela sabedoria, nos diz Sêneca, que alcançaremos essa liberdade, ou seja, sabedoria e liberdade se exigem mutuamente: Et hanc tibi uiam dabit philosophia. Ad hanc te confer, si uis saluus esse, si securus, si beatus, denique si uis esse, quod est maximum, liber: hoc contingere aliter non potest ${ }^{16}$.

A toda mente sadia é evidente que a absoluta libertas de Sêneca, como a liberdade que vem regendo todas as lutas filosóficas e as revoluções cruentas e incruentas da história humana, lembra (passem-me o vulgar da comparação) as lutas de facções dentro de uma prisão, pois, a partir do tempo limitado por um berço e um túmulo, acumulam-se as grades de pressões da educação tradicional de cada povo, dos costumes das épocas, das lindes religiosas, do espaço político, do peso cultural e, mais que tudo, do poder econômico. Atento isso tudo, há que reconhecer que a liberdade absoluta é praticamente um mito, sendo já uma heróica conquista pessoal alcançar a máxima liberdade permitida ao ser humano pelas contingências da vida.

Ora, a liberdade dos povos vem sendo dirigida, ao longo dos tempos, já pela força exterior, já pela interior ao homem. A força externa é a violência armada (manu militari), a interna é convicção pessoal, mas que pode ser obtida pela persuasão democrática, ou demagógica, quando o receptor é falto das defezas do saber, ignorante das armadilhas de uma lógica falaciosa ou é vítima das paixões. A retórica, essa arte da palavra criadora de persuasão, com capacidade de servir-se da língua em seu poder sugestivo e emotivo, para persuadir ouvintes e obter o seu consenso ${ }^{17}$ é a própria eloqüência, ligada à sabedoria, que Cícero e Quintiliano davam como a arte de governar os povos pelo $\lambda$ ó os $^{18}$.

A retórica, portanto, constitui-se também uma pressão sobre a liberdade, mas, diríamos, lícita, quando não demagógica, pois influencia uma opção pessoal, pelo fornecimento de dados de conhecimento, embora, e nisto é um tanto abusiva, se valha também da sugestão e da emotividade do ouvinte, que estão vinculadas ao influxo da vontade sobre a razão.

É claro que, quando o poder político se concentra nas mãos de um só, como sucedeu no período de toda a vida de Tácito, sob governos ora mais, ora menos tirânicos, embora o Historiador tenha-se referido ao governo de Nerva e Trajano como a um tempo de liberdade, quando "era lícito pensar

16 "E a filosofia te dará esse caminho (vencer as necessidades da vida). Volta-te para ela, se queres ser salvo, estar seguro, feliz, se, enfim, queres ser, o que é o máximo, livre; isto não pode suceder de outra maneira" (Sen. Ad Luc. 37, 3).

${ }^{17}$ Marchese, A. Dizionario di retorica e di stilistica. Milano, Mondadori, 1984, s.v. Retórica.

${ }^{18}$ Michel, 1962, p. 6-7. 
o que se quisessse e dizer o que se pensava (Tac. An. I, I, 6) ${ }^{19}$, essa abertura política, diminuto oásis que fosse, ganhava foros de importância significativa para quem vinha do deserto de cerca de 64 anos de tirania.

Impende não esquecer aqui que, para o romano, essa libertas, se podia referir-se à liberdade pessoal, atinente aos direitos privados do indivíduo, que se opunha à seruitus, dizia respeito principalmente à da vida pública romana, libertas romana por excelência, que não é um direito inato ao homem, mas adquirido como ciuis romanus. Dela nos fala Cícero (Cic. Phil. VI, VII, 19): Aliae nationes seruitutem pati possunt, populi Romani est propria libertas. (Pereira, 1984, p. 368-373) ${ }^{20}$.

À luz desses conceitos é que cumpre entender toda a libertas de que se fale aqui. Se, na época da história de Roma que hoje denominamos republicana, a eloqüência política foi móvel de grandes mudanças, no Império era quase suicídio desafiar o poder único pelo debate político. A oratória derivou, então para outras áreas: processos civis, procesos políticos da parte do governo contra desafetos, processos de lesa-majestade que enriqueceram advogados do principado.

Como observamos atrás, no rápido exame da introdução do Dialogus, a razão de ser desta obra é dar uma resposta à questão feita a Tácito pelo amigo Fábio Justo, "quais as causas da decadência da oratória na época?". Apesar da longa e decidida defesa e apologia da eloqüência de seu tempo, feita por Apro, que não a considerava inferior à do período de Cícero, dentro do todo do Dialogus a impresão que se tem é de que só ele assim realmente pensava, se pensava... A eloqüência, ao longo dos anos do Império viera realmente se transformando no servilismo acima referido, jamais ousando contra o príncipe sem que fosse calada pela força.

E quais os motivos dessa decadência? Há os claramente denunciados pelos por assim dizer acusadores da decadência, Vipstano Messala, que carrega na educação deficiente dos jovens, nos temas fúteis e vazios de seus exercícios, na charlatanice dos rétores, na ausência de sólida cultura, na redução do ofício político da oratória, no menosprezo dos dotes morais, e Curiácio Materno, defensor da superioridade da poesia sobre a eloqüência, o qual, com a leitura das sua tragédia Catão, teria ofendido os poderosos, mas que, a menos que irônico tenha sido, incrimina a grande e notável eloqüência de outrora como filha da licença que, diz ele, os tolos soem chamar liberdade. E há também motivos que se podem entrever nas próprias asserções com que Marco Apro pretende defender a oratória contemporânea, quando apresenta

\footnotetext{
${ }^{19}$ Rara temporum felicitate ubi sentire quae uelis et quae sentias dicere licet.

20 "Outras nações podem ser passivas de servidão, mas a liberdade é um privilégio do povo romano".
} 
os objetivos pouco nobres que a mantinham então: promoção individual e social; arma para defesa pessoal, de parentes e amigos; meio pelo qual alguém de berço humilde pode tornar-se respeitado dos grandes.

Não é, pois, de estranhar que se tornem conhecidos apenas rétores de saudação, advogados corruptos, prontos a participar das causas mais ignóbeis, quer na defesa quer no ataque, como v.g. os delatores, que se fizeram notáveis, mesmo porque alguns foram excelentes oradores, embora malversando seus dons de eloqüência e saber, como Éprio Marcelo, Víbio Crispo e até Marco Aquílio Régulo, considerado no Dialogus o maior advogado da época de Trajano, mas que iniciara a sua carreira arruinando duas ilustres famílias, "na esperança de tornar-se poderoso": ... sponte senum consularium accusationem subisse iuuenis admodum, nec depellendi periculi sed in spem potentiae uidebatur ${ }^{21}$. Se de Régulo se fala com respeito no Dialogus, cumpre lembrar que ele era meio-irmão de Messala, um dos interlocutores e apologista da oratória republicana.

Essa, portanto, a oratória que sobrevivia, então, "modelo da eloqüência forense dos acusadores, aquela eloqüência que jorrava sangue e tresandava a ganhos ilícitos", no dizer de R. Syme ${ }^{22}$. E é o meio-irmão de Régulo, Messala, cujas censuras à primeira educação relatamos atrás, quem retoma o tema, visando agora à retórica:

Quis enim ignorat et eloquentiam et ceteras artes desciuisse ab illa uetere gloria non inopia hominum, sed desidia iuuentutis et neglegentia parentum et inscientia praecipientium et obliuione moris antiqui? ${ }^{23}$

Iniciando com a figura da preterição, Messala especifica o tipo de ensino e de escolas de retórica que patrocinavam esse descalabro:

Transeo prima discentium elementa, in quibus et ipsis parum laboratur: nec in auctoribus cognoscendis nec in euoluenda antiquitate nec in notitia rerum uel hominum uel temporum satis operae insumitur. Sed expetuntur quos rhetoras uocant; (...)

21 "Parece que (Régulo) bem jovem ainda tomou a si de bom grado a acusação dos velhos consulares e não para afastar algum perigo pessoal, mas na esperança do poder" (Tac.An. XLII, 2).

${ }^{22}$ Syme, R. Tacitus. Oxford, Clarendon Press, 1958. Cf. Fedel, P. Letteratura latina. Napoli, Edizioni “Il Tripode", 1986, p. 399-403.

23 "Quem, na verdade, ignora que não só a eloqüência como as demais artes degeneraram daquela velha glória, não pela falta de homens, mas pelo descaso da juventude, pela negligência dos pais, pela ignorância dos mestres e pelo esquecimento dos costumes antigos?" (Tac. Dial. XXVIII, 2). 
Sed ut dicere institueram, deducuntur in scholas, in quibus non facile dixerim utrumne locus ipse an condiscipuli an genus studiorum plus mali ingeniis adferant. Nam in loco nihil reuerentiae est, in quem nemo nisi aeque imperitus intrat; in condiscipulis nihil profectus, cum pueri inter pueros et adulescentuli inter adulescentulos pari securitate et dicant et audiantur; ipsae uero exercitationes magna ex parte contrariae.

Sequitur autem, ut materiae abhorrenti a ueritate declamatio quoque adhibeatur. Sic fit ut tyrannicidarum praemia aut uitiatarum electiones aut pestilentiae remedia aut incesta matrum aut quidquid in schola cotidie agitur, in foro uel raro uel numquam ingentibus uerbis persequantur: ... ${ }^{24}$

A esse quadro de desando na formação escolar dos jovens de seu tempo Messsala contrapõe o empenho dos grandes oradores de outrora no enriquecimento cultural, valendo-se do exemplo de Cícero, que deixou no vasto cabedal de conhecimentos de suas obras o porquê de seu poder de eloqüência:

Itaque hercule in libris Ciceronis deprehendere licet, non geometriae, non musicae, non grammaticae, non denique ullius ingenuae artis scientiam ei defuisse. Ille dialecticae subtilitatem, ille moralis partis utilitatem, ille rerum motus causasque cognouerat. Ita est enim, optimi uiri, ita est, ex multa eruditione et plurimis artibus et omnium rerum scientia exundat et exuberat illa admirabilis eloquentia; neque orationis uis et facultas, sicut ceterarum rerum, angustis et breuibus terminis cluditur, sed is est orator, qui de omni quaestione pulchre et ornate et ad persuadendum apte dicere pro dignitate rerum, ad utilitatem temporum, cum uoluptate audientium possit. ${ }^{25}$

24 "Não vou falar dos conhecimentos elementares dos que aprendem, conhecimentos nos quais e para os quais pouco se trabalha. Nem no conhecimento dos autores, nem na consideração da antigüidade, nem na ciência já das coisas, já dos homens, já dos tempos emprega-se o trabalho suficiente. Mas procuram-se aqueles chamados rétores ......... Mas, como eu tinha começado a dizer, (nossos adolescentes) são conduzidos às escolas, nas quais eu não saberia dizer se o próprio lugar, se os colegas ou o tipo de estudos trarão aos espíritos o maior mal. Com efeito, nenhum respeito existe num lugar no qual ninguém entra senão igualmente incapaz; nos condiscípulos, nenhum proveito, visto que meninos entre meninos e adolescentes entre adolescentes falam e são ouvidos com igual insegurança; mas os próprios exercícios são, na maior parte, contraproducentes ......... Segue-se ainda que a isso se junta também o fato de o assunto da declamação estar distante da realidade. Sucede assim que as recompensas dos tiranicidas ou as alternativas das violentadas, ou os remédios da peste ou os incestos das mães ou seja o que for que é tratado cada dia na escola, raramentre ou nunca é tratado no fórum em tom enfático" (Tac. Dial. XXX, 1-2 e XXXV, 2-5).

25 "Pode-se assim ver nas obras de Cícero que não lhe faltou conhecimento nem de geometria, nem de música, nem de gramática, nem, enfim, de de qualquer das artes liberais. Ele aprendera a sutileza da dialética, a aplicação do âmbito moral e os movimentos e 
$\mathrm{Na}$ exposição que faz sobre a superficialidade da educação da sua época como uma das causas da decadência da oratória, Messala imagina que alguém possa asseverar que basta, de acordo com as conjunturas, seja o orador medianamente instruído com algo superficial e simples... Mas, objeta ele, qualquer pessoa, mesmo do povo, percebe se que o orador fala do que sabe, de algo que lhe é próprio ou se discorre sobre assunto tomado de empréstimo.

Quod adeo neglegitur ab horum temporum disertis, ut in actionibus eorum huius quoque cotidiani sermonis foeda ac pudenda uitia deprehendantur; ut ignorent leges, non teneant senatus consulta, ius huius ciuitatis ultra derideant, sapientiae uero studium et praecepta prudentium penitus reformident. In paucissimos sensus et angustas sententias detrudunt eloquentiam uelut expulsam regno suo, ut quae olim omnium artium domina pulcherrimo comitatu pectora implebat, nunc circuncisa et amputata, sine apparatu, sine honore, paene dixerim sine ingenuitate, quasi una ex sordidissimis artificiis discatur. ${ }^{26}$

Quintiliano, mais comprometido com o poder político do que Tácito, já que era professor às expensas do Estado, ao referir-se à decadência, cingese apenas ao problema da educação. O autor do Dialogus vai além e acusa o mau uso da retórica pelos declamadores, pelos delatores, pelos advogados vendidos e interresseiros, e ousa trazer à arena da discussão o problema da eloqüência ante a falta de liberdade política, mas em acusação velada, num duvidoso, se não irônico, elogio ao compensatório benefício da paz, da tranqüilidade, como se no Império se vivesse melhor do que na República, apesar das restrições maiores ou menores à liberdade.

as causas da natureza. Assim é, excelentes amigos, assim é que, de uma grande erudição, de inúmeros conhecimentos e de uma ciência universal mana em abundância e transborda aquela admirável eloqüência; a força e o exuberante do discurso não se encerram, como os das demais coisas, em estreitos e exíguos limites, mas é orador aquele que puder, a respeito de qualquer tema, falar bem, com elegância e com propriedade, de acordo com a dignidade do assunto, para persuadir, valendo-se da vantagem das circunstâncias e com agrado dos ouvintes" (Tac. Dial. XXX, 4-5).

26 "Isso é de tal sorte negligenciado pelos eloqüentes destes tempos, que, em seus discursos forenses, se encontram até os defeitos feios e vergonhosos de nossa fala cotidiana; de sorte que ignoram as leis, desconhecem os senatus-consultos, zombam, além disso, do direito civil; de sorte que ao estudo da sabedoria, então, e aos preceitos dos sábios têm profundo horror. Reduzem a eloqüência, como que banida de seu reino, a pouquíssimas idéias e a tiradas concisas, de maneira que ela, que outrora, senhora de todas as ciências, enchia as mentes com um cortejo magnífico, agora, reduzida e amputada, sem pompa, sem honra, diria quase sem liberdade, é aprendida como se fosse uma das mais sórdidas ocupações" (Tac. Dial. XXXII, 3-4). 
Curiosamente, de Materno, o defensor da poesia em oposição a uma eloqüência decadente, poesia capaz de eternizar a lembrança de alguém mais que essa oratória em declínio, dele parte a afirmação difícil de explicar sem o veso irônico, atento o nível cultural do emisssor:

... sed est magna illa et notabilis eloquentia alumna licentiae, quam stulti libertatem uocitant, comes seditionum, effrenati populi incitamentum, sine obsequio, sine seueritate, contumax, temeraria, adrogans, quae in bene constitutis ciuitatibus non oritur. ${ }^{27}$

Espanta ouvir, sem pensar em ironia, a argumentação de Materno sobre a inexistência de oradores entre Macedônios, Persas, Lacedemônios. Houve alguns em Rodes, mas muitíssimos houve atenienses, entre os quais o povo podia tudo, tudo podiam os incompetentes, e todos, por assim dizer, podiam todas as coisas... So faltou dizer que a eloqüência é fruto da anarquia!

E de que adianta a grande eloqüência ? Não leva a nada, pois o que aproveitou a Cícero, já que o levou à morte? ...nec bene famam eloquentiae Cicero tali exitu pensauit ${ }^{28}$.

O que Materno acrescenta a seguir, a menos que irônico, raia por uma cândida desfaçatez, num intelectual esclarecido que vivera praticamente sob Nero, Galba, Otão, Vitélio, Domiciano et caterua:

Quod si inueniretur aliqua ciuitas, in qua nemo peccaret, superuacuus esset inter innocentis orator sicut inter sanos medicus. Quo modo tamen minimum usus minimumque profectus ars medentis habet in iis gentibus, quae firmissima ualetudine ac saluberrimis corporibus utuntur, sic minor oratorum honor obscuriorque gloria est inter bonos mores et obsequium regentis paratos. Quid enim opus est longis in senatu sententiis, cum optimi cito consensiant? quid multis apud populum contionibus, cum de re publica non imperiti et multi deliberent, sed sapientissimus et unus? Quid uoluntariis accusationibus, cum tam raro et tam parce peccetur? quid inuidiosis et excedentibus modum defensionibus, cum clementia cognoscentis obuiam periclitantibus eat? ${ }^{29}$

27 "Mas essa grande e notável eloqüência (de outrora) alimenta-se da licença, a que os tolos soem chamar liberdade e é companheira das sedições, incitamento de um povo infrene, insubmisssa e sem seriedade, rebelde, temerária, arrogante, e não nasce nunca nos Estados bem constituídos" (Tac. Dial. XL, 2).

28 "...nem Cícero compensou bem a fama de sua eloqüência com o fim que teve" (Tac. Dial. XL, 4).

29 "Se se encontrasse um Estado no qual ninguém prevaricasse, seria desnecessário entre inocentes o orador, como o é o médico entre pessoas sadias. Da mesma maneira que a arte de curar tem o mínimo de utilidade e o mínimo de proveito entre os povos que gozam de robustíssima saúde e de corpos salubérrimos, assim menor é a honra dos oradores e mais 
Reduzindo, simploriamente, os efeitos da eloqüência a uma grande fama pelo preço da intranqüilidade, Materno encerra sua fala, sem qualquer referência aos tipos possíveis do uso da oratória, nem sequer à demagógica: ...quoniam nemo eodem tempore adsequi potest magnam famam et magnam quietem, bono saeculi sui quisque citra obtrectationem alterius utatur ${ }^{30}$.

Após umas poucas linhas, cujo conteúdo não vai além de uma troca de brincadeiras amigas, o narrador fecha o Dialogus com uma frase, que, penso eu, talvez coubesse melhor logo depois da última fala de Materno, que acabamos de ler: Cum adrisissent, discedimus" ${ }^{\prime 31}$.

Tácito é um historiador por extremo cuidadoso em não revelar sua visão filosófica das coisas que, ao que parece, não ia além dos elementos estóicos dos homens cultos de sua época, mas, de qualquer sorte, era zeloso em ocultar suas opiniões políticas, que por certo as tinha, já que aprendera, ao longo dos anos, a não dar motivos para acusações perigosas, que conhecia a preceito pelo que revela nos Annales e nas Historiae, bem como nas obras menores.

A arte de sobreviver com a menor desonra possível nas mais perigosas circunstâncias parece ter sido uma das especialidades de Tácito, que vira filósofos expulsos e oradores ousados perecerem sob vários imperadores. Dois mil anos antes do velho Santiago de "O velho e o mar", o nosso Historiador percebeu muito bem que não era o momento de pensar sobre o que não tinha, mas de pensar sobre o que fazer com o que tinha. É a acomodação ao momento de que Éprio Marcelo fala, defendendo-se de seus acusadores, como relatam as Historiae: se meminisse temporum quibus natus sit, quam ciuitatis formam patres auique instituerint; ulteriora mirari, praesentia sequi; bonos imperatores uoto expetere, qualiscumque tolerare ${ }^{32}$.

Pelo que escreve nos Annales, Tácito não se declara favorável a uma determinada forma de governo: nam cunctas nationes et urbes populus aut

obscura sua glória entre os bons costumes e entre aqueles que se dispõem à obediência ao governante. Que necessidade há, pois, de longos discursos no senado, quando os melhores entram para logo em acordo? Por que muitos discursos perante o povo, já que não são os incompetentes nem muitos que deliberam sobre os interesses do Estado, mas um só e o mais sábio? Por que tomar a iniciativa das acusações, quando tão raramente e tão pouco se prevarica? Por que defesas odiosas e sem comedimento, quando a clemência de quem decide vai ao encontro dos acusados?" (Tac. Dial. XLI, 3-4).

30 “... uma vez que ninguém pode usufruir, a um só tempo, de uma grande fama e de uma grande paz, que cada um aproveite a vantagem de sua época, sem criticar a de outra" (Tac. Dial. XLI, 5).

31 "Tendo todos rido, nós nos separamos" (Tac. Dial. XLII, 2).

32 "Que se lembra do tempo em que nascera, da forma de governo que seus pais e antepassados tinham estabelecido. Que admira o passado, mas se acomoda ao presente. Imperadores, ele os deseja bons, mas os toleraria quaisquer que fossem" (Tac. Hist. IV, VIII, 4). 
primores aut singuli regunt: delecta ex iis et consociata rei publicae forma laudari facilius quam euenire, uel, si euenit, haud diuturna esse potest ${ }^{33}$.

Essa acomodação tinha, evidentemente, um preço e Tácito, um homem de consciência, ao que parece, di-lo, vez por outra. Como observa Alain Michel $^{34}$, Tácito, no Senado, viveu sob a pressão dos soldados de Domiciano e foi obrigado, para sobreviver, a aceitar e votar condenações de pessoas que admirava. Há, por exemplo, em seu relato das atrocidades de Domiciano, pronomes pessoais e possessivos que entremostram certa mágoa embaraçosa: mox nostrae duxere Heluidium in carcerem manus; nos Mauricum Rusticumque diuisimus, nos innocenti sanguine Senecio perfudit $t^{35}$.

Ainda no Agrícola, em estranho contraste com a resignada acomodação proposta pelo poeta Curiácio Materno no final do Dialogus, é bastante clara a asserção de Tácito: ... et, sicut uetus aetas uidit quid ultimum in libertate esset, ita nos quid in seruitute, adempto per inquisitiones etiam loquendi audiendique commercio ${ }^{36}$.

Consideradas essas e outras reflexões de Tácito em suas obras, tornase difícil acreditar que, embora mais novo fosse ao escrever o Dialogus, ele estivesse intimamente de acordo com as palavras finais que põe na boca de Materno, numa afirmativa sincera de aceitação dos limites de vida, de palavra e de pensamento que o Príncipe lhe impunha. Daí ser bem mais aceitável uma velada ironia...

É bem provável que, hábil que era politicamente e dotado da cultura excelente que lhe advinha já de Quintiliano, já de amigos como Plínio, já dos conhecimentos históricos, tenha substituído a eloqüência suicida da contraposição ao poder tirânico, pela eloqüência da narrativa histórica bem trabalhada, despojada o quanto possível de considerações pessoais, mas capaz de acordar no íntimo do leitor, longe do alcance do tirano, as conclusões normais de todo ser humano perante as barbaridade e injustiças do poder absoluto.

Por que não pensar que o celebrado pessimismo de Tácito, ao longo das Historiae e dos Annales, seja mais que um simples estado de alma do autor, em face dos descalabros do Império, e tenha-se tornado, inteligente-

33 "Com efeito, a todas as nações e cidades, governam-nas ou o povo ou os homens importantes ou um só: uma forma de Estado provinda dessas (três), associando-as, seria mais fácil de louvar do que de acontecer ou, se acontecesse, não poderia ser duradoura" (Tac. An. IV, XXXIII, 1).

${ }^{34}$ Michel, 1982, p. 50.

35 "Em seguida, nossas mãos conduziram Helvídio ao cárcere, nós separamos Maurico e Rústico, a nós Senécio nos banhou com seu sangue inocente” (Tac. Agr. XLV, 2).

36 "Como os tempos antigos viram o que havia de extremo em liberdade, assim nós conhecemos o que havia de extremo em servidão, já que nos foi tirado, por meio da espionagem, até o relacionamento do falar e do ouvir" (Tac. Agr. II, 3). 
mente, arma de uma eloqüência, única então possível, contra a ausência da liberdade? Quando se tornara inexeqüível apontar o certo e o errado, como o fizera a liberdade da República, só restava aos que viam, relatar os acertos e erros do passado, para que os habituados ao não pensar pelo poder autoritário, pudessem, por si mesmos, ter o senso do instante que viviam. A história, ainda que obra literária na época, substituiria assim, de alguma maneira, as formas mais livres da eloqüência anterior ao Império.

É o próprio Tácito que, tentando justificar a história que escreve, onde se relatam, "inúmeras sentenças cruéis, acusações contínuas, falsas amizades, perseguições de inocentes, causas de morte sempre idênticas", apresenta o motivo:

Igitur ut olim plebe ualida, uel cum patres pollerent, noscendi uulgi natura et quibus modis temperanter haberetur, senatusque et optimatium ingenia qui maxime perdidicerant, callidi temporum et sapientes credebantur. Sic conuerso statu neque alia re Romana quam si unus imperitet, haec conquiri tradique in rem fuerit, quia pauci prudentia honesta $\mathrm{ab}$ deterioribus, utilia ab noxiis discernunt, plures aliorum euentis docentur. ${ }^{37}$

\section{Bibliografia selecionada}

Albrecht, M. Storia della Letteratura Latina. (trad. De A. Setaioli). Torino, Giulio Enaudi, vol. II, 1995.

André, J.-M. La philosophie à Rome. Paris, Presses Universitaires de France, 1977.

Boissier, G. Tacite. Paris, Librairie Hachette, 1908.

Cova, P.V. Lo stoico imperfetto. Napoli, Società Editrice Napoletana, 1978.

Gianotti, G.F.; Pennacini, A. Società e comunicazione letteraria di Roma antica. 2a ed. Torino, Loescher Editore, 1990.

Lalande, A. Vocabulaire technique et critique de la philosophie. Paris, Presses Universitaires de France, 1972.

La Penna, A. La cultura letteraria a Roma. Roma-Bari, Editori Laterza, 1986.

Levi, A. Historia de la Filosofia Romana. Trad. de Héctor Pozzi. Buenos Aires, Eudeba Editorial Universitaria de Buenos Aires, 1969.

37 "Portanto, assim como outrora, quando a plebe era forte ou quando o senado era poderoso e cumpria conhecer o caráter do povo e por que meios pudesse ser tratado sensatamente, os que haviam estudado a fundo o espírito do senado e dos otimates eram tidos por políticos habilidosos e sábios, assim também, invertida a situação política e não se encontrando o Estado Romano em situação diversa da de uma monarquia, será proveitoso buscar e relatar esses fatos, porque poucos são capazes de discernir, com critério, o honesto do aviltante, o útil do prejudicial; a maior parte aprende com o que acontece aos outros" (Tac. An. IV,XXXIII,2). 
Martin Sanchez, M.A.F. El ideal del sábio en Seneca. Cordoba, Imprensa San Pablo, 1984.

MARIotTI, I. Storia e testi dalla litteratura latina. Bologna, Zanichelli Editore, vol. II, 1986.

Peters, F.F. Termos filosóficos gregos. Trad. Beatriz R. Barbosa. Lisboa, Calouste Kulbenkian, $2^{\text {a }}$. ed., 1983.

___ Tácito e il destino dell'Impero. Trad. Alfredo Salsano. Torino, Enaudi, $3^{\text {a }}$. ed., 1982.

Piganiol, A. Historia de Roma. Trad. de Ricardo Anaya. Buenos Aires, Editorial Universitaria de Buenos Aires, $3^{\text {a }}$. ed., 1974.

SenecA. Lettere a Lucilio. Milano, Rizzoli Editore, 1985.

TACite. Dialogue des orateurs. Introdução e notas de H. Goelzer. Paris, Librairie Hachette, $4^{\text {a }}$. ed., 1908.

—_ Dialogues des orateurs. Paris, Les Belles Lettres, 3a. ed., 1947.

—_ Histoires. Paris, Les Belles Lettres, 1949-1951.

___ Annales. Paris, Les Belles Lettrres, 1953-1978.

—_ Vie d'Agricola. Paris, Les Belles Lettres, 2a . ed., 1948.

TÁcito. Obras Menores. Trad. e nota prévia de Agostinho da Silva). Lisboa, Livros Horizonte Ltda., 1974.

RÉSumÉ. Éloquence, liberté et éducation dans le "Dialogus de oratoribus". Ce travail vise à soumettre au lecteur d'aujourd'hui dés idées et des faits sélectionnés dans le Dialogus de oratoribus de Tacite, afin de l'aider à mieux comprendre la signification de la plus ou moins grande liberté d'être et de s'exprimer, selon le système politique et éducatif, ainsi que le role de l'éloquence dans cette liberté. L'art oratoire, considéré comme décadent à l'époque de Tacite, bien que vu à la fois comme protecteur et salvateur, est rarement, presque avec crainte, traité à la lumière de la politique dominante. L'éducation inefficace et la "paix" politique seraint les causes de cette décadence à l'époque impériale. Pour les romains, la liberté proprement dite, la absoluta libertas, dépend initialement dés éducateurs. La liberté est également conditionnée au niveau de la connaissance, dans le domanine de laquelle la persuasion "democratique" de l'éloquence peut agir de façon licite, et à une politique capable de respecter cette liberté. Sous l'Empire, l'éloquence ne se suiciderait pas, em osant contre le prince. De lá, aux dires de Syme, que l'art oratoire qui survivait alors était le "modèle de l'éloquence des accusateurs au barreau, cette éloquence sanglante qui empestait le profit illicite". Les écoles avaient là dedans une part de responsabilité, en vertu de la superficialité de l'éducation à cette époque. Ayant vécu et vivant encore sous le joug des empereurs, tout em laissant entrevoir son angoisse, Tacite s'acommode pour survivre mais découvre un moyen d'enseigner la vérité, en racontant les évènements du passé, car la plupart des gens apprennent avec ce qui arrive aux autres (plures aliorum euentis docentur).

Mots-Clés. Dialogus de oratoribus; Tacite; rhétorique; éloquence; liberté; éducation. 